\title{
DEVELOPMENTS IN BIOTECHNOLOGY: PROGRESS, PROBLEMS AND PROSPECTS
}

\author{
RANJAN RAMASAMY \\ Steering Committee on Biotechnology, Natural Resources, Energy and Science Authority, \\ Colombo 7 .
}

(Received: 05 May 1998; accepted: 06 November 1998)

\begin{abstract}
The development of Biotechnology in Sri Lanka is reviewed in the context of similar developments elsewhere, with special reference to India, Brazil and developed countries. Support for Biotechnology from overseas research funding agrencies and the Natural Resources, Energy and Science. Authority (NARESA) Lnow the National Science Foundation (NSF) ] is outlined. A NARESA Steering Committee on Biotechnology, first established in 1992 plays a key role in promoting Biotechnology in Sri Lanka.
\end{abstract}

Key words: Biotechnology, NARESA, research funcling

\section{INTRODUCTION}

Biotechnology in its broadest sense is the use of other organisms for producing the needs of human beings. In such a context, biotechnology is as old as human civilisation ${ }^{1}$. For example, wild grass varieties were selected and grown as wheat in the Middle East in 9000 BC, and as rice in South and East Asia in 4500 BC. Cotton was cultivated in the Indus valley by $3000 \mathrm{BC}$. Alcoholic beverages have been produced by fermentation since recorded history. Recent advances in cellular and molecular biology have however dramatically enhanced our ability to manipulate cells, microorganisms and indeed human beings and other mammals. Some landmark discoveries made in this century include the demonstration in 1941 by Beadle \& Tatum that a single gene codes for a single protein, Avery's proof in 1944 that DNA is the genetic material, elucidation of DNA structure in 1953 by Watson \& Crick, the discoveries of restriction enzymes, DNA polymerase, reverse transcriptase etc., that permitted gene cloning, the production of monoclonal antibodies in 1975 by Kohler \& Milstein and more recently the discovery of the polymerase chain reaction to amplify specific regions of DNA molecules. Considering the recent scientific discoveries and technological advances, the European Federation of Biotechnology in 1981 adopted a useful working definition of biotechnology as "the integrated use of biochemistry, microbiology and chemical engineering to achieve the technological applications of the capacities of microbes and cultured cells ". 


\section{DEVELOPMENTS IN BIOTECHNOLOGY IN OTHER COUNIRIES}

The impact of biotechnology on the economy, health, agxiculture, industrial production and the environment was recognised very early in Japan and countries in North America and Europe. This was due to their advanced industrial / economic forecasting and planning capabilities. A few other countries, notably Argentina, Australia, Brazil, India, and Thailand were also able to grasp, at a relatively carly stage, the possibilities inherent in bioteclonology. As a result, these countries could set up the necessary infirastructure to plan and develop human resources, institutions and funding early enough to take advantage of the subsequent rapid expansion in biotechnology that took place in the 1980 s and $1990 \mathrm{~s}$.

For a long time in India, the only institutes engaged in advanced experimental biological research were the Indian Institute of Science- Bangalore, the National Chemical Laboratory - Pune and the Department of Applied Chemistry Calcutta. In 1981 the Centre for Cellular and Molecular Biology ( CCMB) was set up in Hyderabad by the Council of Scientific and Industrial Research and a few years later the National Institute of Immunology (NII) was opened in New Dejhi by the Department of Science and Technology. In the Indian 6th tive yeas development plan (1980-1985) priority arcas for research in lite sciences, including Biotechnology, were explicitly included." In the 7th plan ( 1986-1990), emphasis in these areas was shifted to human resources development, projects involving several disciplines and research and development into biotechnology derived products. Ambitious programmes in biotechnology were also included in the 8th five-year plan (1991-1996). As early as 1982, a National Biotechnology Board ( NBTB ) was set up in India for which the Department of Science and Technology provided secretarial services. The aim of this initiative was to coordinate the research and development carried out in various ministries or services e.g. the Department of Science and Technology, the Indian Council of Medical Research, the Indian Council of Agricultural Research and the University Grants Commission. The NBTB drew up a Iong term plan for the development of Biotechnology in India based on achieving food sell-sufficiency, better health and hygiene, environmental protection and industrial growth. A few years after its creation, in 1986 , the NBTB was replaced by a separate government department, the Department of Biotechnology (DBT), headed by a Secretary who reported directly to the Prime Minister. Dr. S. Ramachandran who headed the new Department, played a key role in the subsequent far rcaching achievements of India in the field of Biotechnology. Among its recent accomplishments was negotiating the location of a part of the International Centre for Genetic Engineering and Biotechnology (ICGEB) in New Delhi. The ICGEB laboratories functioned for several years in laboratories provided by the NIl, before moving to their own campus nearby in 1997. The ICGEB is anticipated to play a major role in the development of Biotechnology in India. The 
budget for the DBT in the 7th five-year plan was U.S. $\$ 200$ million. Among the programmes supported by DBT that have since made substantial accomplishments are:

- development of larval insecticides against mosquitoes

- extraction of low grade copper ore by bacterial leaching

- tissue culture propagation of bamboo, coconut and cardamom

- optimising ethanol production

- increased production of antibiotics locally

- production of insulin

- production of follicle stimulating hormone and human chorionic gonadotropin

- contraceptive vaccine for animals

- raising of elite timber varieties for forestry

- diagnostic kits for infectious diseases such as HIV

- vaccines for infectious diseases such as hepatitis $B$

More recently, $\mathrm{Dr}$ (Mrs) Manju Sharma as the Secretary in charge of Biotechnology has promoted bilateral links in Biotechnology between India and other countries. For example, in 1998 cooperation with France in the fields of bioinformatics, genes of the human $\mathrm{X}$ chromosome, silkworm genome and epilepsy genes, involving training, information exchange and scientific visits, was initiated. A similar programme of cooperation with Sri Lanka involving the development of DNA probes for anopheline mosquitoes, use of microbes in bioremediation and mining, plant genetic engineering and natural products is being developed. A related initiative is the proposal to establish a SAARC Committee on Biotechnology that would serve to promote the development of Biotechnology among member nations.

Moving further away, to Brazil, biotechnology research was until 1981 done under the umbrella of Agricultural research. In 1981 a National Biotechnology Programme was set up linked to the Planning Ministry and the National Research Council ${ }^{2}$. This programme received funding from the Government and the World Bank under the programme to support science and technology development in Brazil since 1984. World bank loans to the tune of about U.S. \$92 million were used to set up the programme. A Laboratory of Plant Genetic Engineering was established within the National Centre for Genetic Resources in 1981, which in 1986 became the National Centre for Genetic Resources and Biotechnology. Large agribusiness firms such as Agroceres SA were involved in biotechnology research and development e.g. hybrid seeds, disease free potato tubers etc. Regional cooperation in Biotechnology has been strong with the establishment of the Argentina-Brazil Centre for Biotechnology that initially dealt with application of immobilised enzymes for industrial production. Several institutions throughout the country, some funded by States, and others by the Federal Government, have been engaged in biotechnology research and development. A Bio-Rio Science-Industry Park was set up in 1989 
in Rio de Janeiro, supported by the Federal Government, the city of Rio and private sources. The Park aimed to generate U.S. $\$ 250$ million worth of annual sales in the year 2000. The main objectives of the Park were:

- integration of basic and applied research in biotechnology

- technology development and transfer

- development of bio-industry with priority to health, agriculture, energy and the environment

- manpower training

- promotion of technology based joint ventures

- international cooperation

The private sector in Brazil has been very active in Biotechnology. For example, Agroceres SA, a large agro-industrial corporation created in 1945 is presently engaged in plant genetics research, the production of hybrid seeds, animal breeding and development of animal feedstuffs among other biotechnology activities.

In the U.S., Europe and Japan, private sector companies have mushroomed to take advantage of the major new discoveries being made in universities and rescarch institutes. Often these have been founded by the researchers involved in making the discoveries. Biotechnology companies such as Genetech achieved listing on the stock exchange to increase their assets and capabilities. These companies in turn began to fund research relevant to Biotechnology in their own laboratories and sometimes in universities. Such research activity in private firms has developed into a major source of new products for Biotechnology. However, the governments in these countries have continued to support the development of Biotechnology through public sector funding. In the U.K. for example, the abolishment of the old Science Research Council was accompanied by the creation of a Biotechnology and Biological Sciences Rescarch Council to fund academic research in the country. There is intense competition anong companies to patent commercially usefiul findings and the Patent Offices have sometimes not been able to handle the complications. This is illustrated for example by the current legal battie over the commercial use of the breast cancer related antigens, BRCA1 and BRCA2, in the U.S. between the companies Oncormed and Myriad. ${ }^{3}$ Advances in Biotechnology have also led to heated debates on ethical aspects e.g. the patentability of human gene sequences or the experimental use of techniques that might lead to cloning of human beings, and envirommental safety e.g. the development of cercals carrying genes for herbicide resistance that allow an casy way of eliminating weeds in the crop but which might also allow the transfer of the resistance gene to related wild relatives of the genetically engineered plant. Biotechnology has also reconty made inroads into the more traditional chemical industries. The use of microorganisms and plants for removing environmental pollutants ranging from heavy metal ions to complex aromatic compounds is 
becoming commonplace. Microorganisms are also being used to concentrate gold from low-grade ores to facilitate subsequent purification of the metal.

\section{BIOTECHNOLOGY IN SRI LANKA}

Biotechnological activities concerned with breeding rice have been carried out for many years in the Research Centres of the Agriculture Department. Several high yiclding varieties, developed mainly by conventional breeding techniques, now account for more than $95 \%$ of the rice grown in the island. Vaccine production at the Medical Research Institute, food technology at the Ceylon Institute of Scientific and Industrial Research and brewing of beer may also be regarded as fringe biotechnology activities that have been ongoing for scveral decades. Plant tissue culture was initiated as a biotechnology activity in 1976 by the Department of Agriculture for the clonal propagation of orchids and anthurium. In 1984 a tissue culture laboratory was established at the Central Agricultural Research Institute with the assistance of the Food and Agricultural Organisation for the micropropagation of fruit crops such as pineapple, citrus, banana, passion fruit and papaya ${ }^{4}$. Mass micropropagation of potato using meristem culture of disease free plants has been undertaken at the Regional Agricultural Research Centre at Bandarawela since 1987. The Plant Genetic Resources Centre established with Japanese assistance in 1988 has advanced facilities to undertake biotechnology research. In vitro conservation of root and tuber crops, callus culture and plant regeneration studies on rice are sume work undertaken at this centre

More recently, research relevant to biotechnology has been initiated at several universities and research institutes. Nearly all the plantation crop research institutes e.g. the Coconut Research Institute ( CRI ) have initiated tissue culture based micropropagation work. Some institutes $\mathrm{e} . \mathrm{g}$. the CRI, have begun using molecular techniques such as Restriction Fragment Length Polymorphism for plant breeding work. Gene cloning studies have been initiated at the Rubber Research Institute. Several university departments have pioneered the use of recombinant DNA techniques. The University of Colombo Department of Biochemistry began cloning of genomic DNA clones for use as probes for Bancroftian filariasis and the Department of Agricultural Biology in the University of Peradeniya started research into genetically engineered plants. The Department of Biochemistry in the University of Jafina has an ongoing programme into enzyme technology, begun under very difficult conditions.

\section{FUNDING FOR BIOTECHNOLOGY IN SRI LANKA}

The biotechnology activities in the various research institutes mentioned above have been funded by the government or international sources at the request of the government. Special funding has also been made available for research 
involving biotechnology by the Council for Agricultural Research Policy. Such research has been carried. out in research institutes and university departments. The Swedish Agency for International Cooperation and the Wolld Health Organisation have generously funded molecular biology research in the Department of Biochemistry, University of Colombo and the malaria research in the Department of Parasitology, University of Colombo respectively. The malaria research programm in Colombo has significant immunological and molecular biological components. Smaller scale funding for research projects and institution strengthening have also been received from the lnternational Foundation for Science and the International Atomic Energy Authority.

To further catalyse biotechnology development in the country, the Natural Resources, Energy and Science Authority established a separate Stecring Committee for Biotechnology in 1992. Apart from selecting and funding projects in Biotechnology, this committee has organised several meetings and seminars to promote biotechnology related activities in the country since 1993. Notably a workshop on Research and Training Needs in Biotechnology was held for the first time at NARESA on $28 \mathrm{May} 1993$ to identify the specific needs of private and public sector end users of Biotechnology and to plan for suitable development of Human Resources in Biotechnology. The proceedings and findings of the workshop were published in a special issue of the Journal of the National Science Council of Sri Lanka." Among the recommendations made by the Steering Commitiee because of this workshop were:

1. Further strengthening of links between the private sector and government research organisations in commercialisation of research,

2. Developing links between different research institutions for collaborations, consultancies and contract-research,

3. Supporting the development of university undergraduate courses in related disciplines such as Cell Biology, Microbiology, Biochemistry, Genetics and Molecular Biology and postgraduate courses in Biotechnology,

4. Identifying an institution to locate large biotechnology projects.

Some of these recommendations have become feasible because a loan has recently been made available for the development of biotechnology from the Asian Development Bank (ADB). The 1997 ADB consultative report ${ }^{\text {ti }}$ also drew attention to shortcomings in the teaching of Biotechnology - related subjects at universities, the need for training scientists and the requirement for large scale infusion of government funds to stimulate biotechnology in the country.

\section{SUPPORT FROM NARESA FOR RESEARCH IN BIOTECHNOLOGY}

Since its inception in 1992, the Steering Committee on Biotechnology has cnabled the award of $R s 8,805,000$ by NARESA in 27 grants for research in various aspects of Biotechnolugy. A further $R s$ 2,582,528 has been recommended 
for funding 5 additional grants in 1998. Details of the grants awarded are shown in Figure 1.

\section{Allocations to areas}

Funds

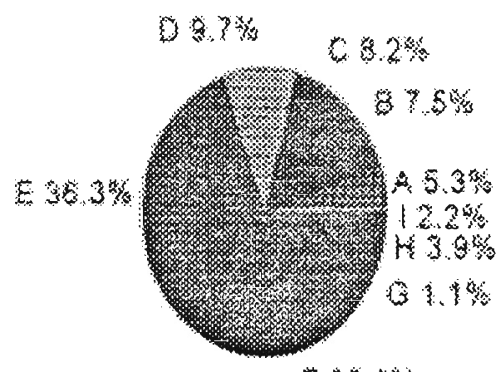

2.3.
No. of progers

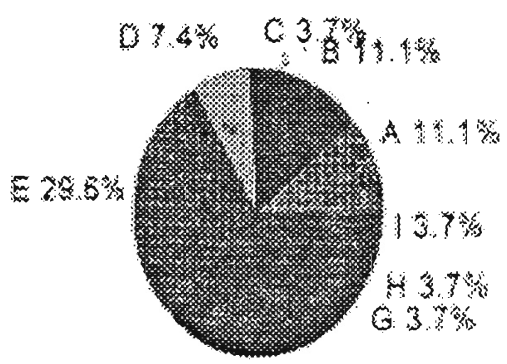

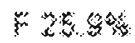

Ligend

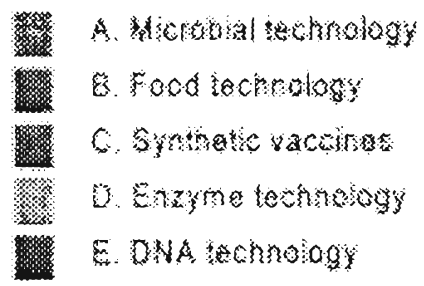

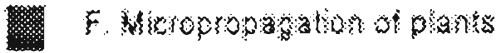

G. Honsons?

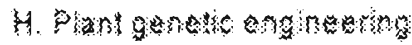

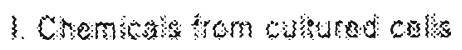

Figure 1: Research grants.

The Committee recognised that equipment needed for Biotechnology are, in general, scarce and expensive. Also reagents for Molecular Biology such as restriction enzymes are unusually expensive materials. Therefore the average Biotechnology grant involves greater expenditure than grants in other fields. In 1995, the funding for research in Biotechnology increased substantially over the previous three years ( Figure 2 ). This was made possible because of a general. increase in funding made available to NARESA consequent to the representations made over several years to different governments. In allocating funds for different projects the Committee was guided by the fact that Biotechnology had to be established almost from scratch, and therefore, in the beginning at least, some flexibility was needed in interpreting a project as Biotechnology. As expertise and interest in Biotechnology increased, the criteria for selection 
would progressively become more focussed on developing new processes and products. In this context, projects with a significant component of molecular biology techniques have sometimes been referred by other NARESA Steering Committees to the Biotechnology Committee for funding purposes due to an absence of the required molecular biological expertise in such Committees.

\section{Research funding for Biotechnology}
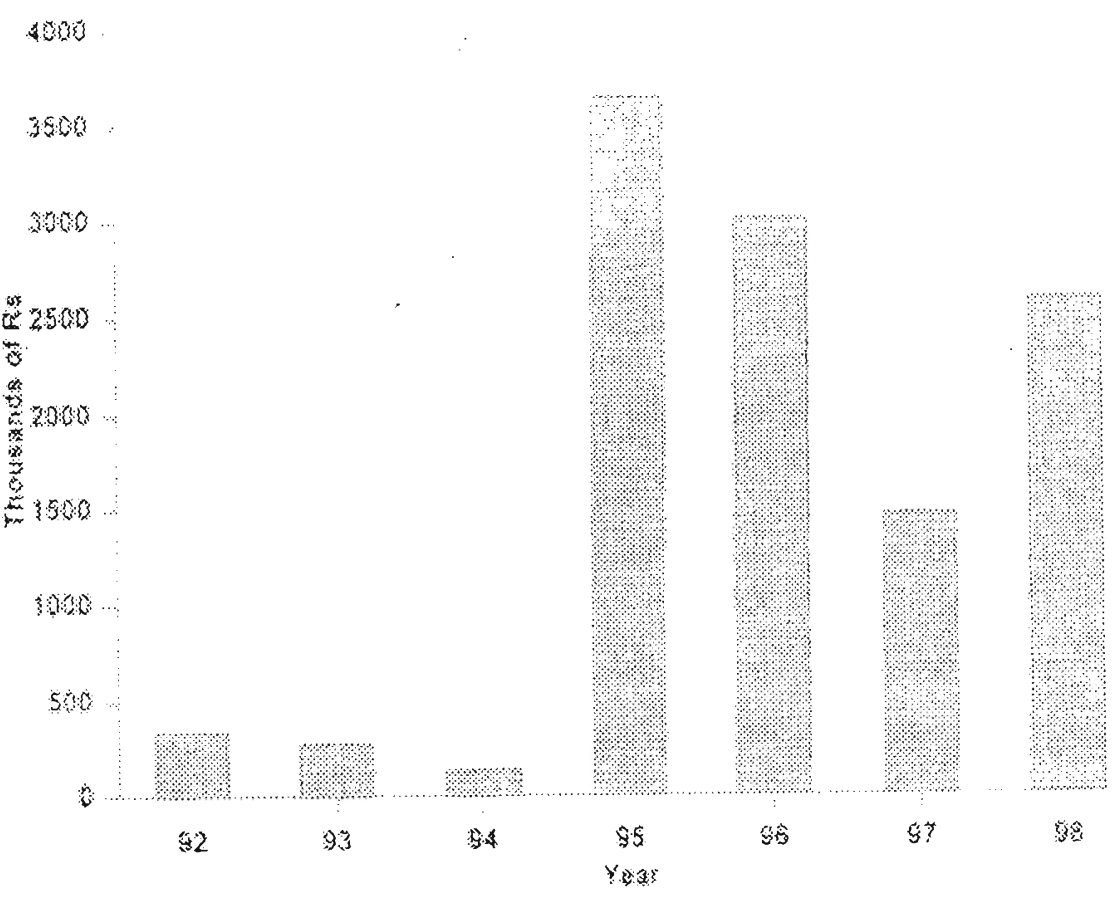

Figure 2: Research funding for biotechnology.

In conclusion it may be said that the NARESA Steering Committee on Biotechnology has had a very significant effect on establishing this important field in universities and research institutes. This is evident from the large number of presentations made in recent years by grantees at various scientific meetings, notably at the Sri Lanka Association for the Advancement of Science annual sessions. At least five papers have also been published in journals such as Biochemical Biophysical Research Communications, Biochimica Biophysica Acta, Bulletin of Entomological Research, International Journal of Biochemistry and Cell Biology, and the Journal of the National Science Council of Sri Lanka. Six research projects have been completed to-date and this has resulted in the award of two PhD degrees based on work supported by NARESA grants. 


\section{PROBLEMS AND PROSPECTS}

The Steering Committee has addressed many issues related to the safety and ethical aspects of Biotechnology work. Since there is no government body at present with expertise to monitor the import of genetically modified organisms, the Committee agreed to do this as an interim measure. The import of microorganisms from foreign countries for biological treatment of waste poses certain problems that the committee discussed often. The Committee also advised on the establishment of new quarantine regulations and proposed that a new quarantine service modelled on the Australian Quarantine service be set up to monitor import/export of all plant, animal and microbial material, including genetically modified organisms.

The Committee also advised on developing guidelines for collaborative research with foreign scientists involving local biological material that could have implications for intellectual property matters. Expert advice on intellectual property rights in Biotechnology will assume greater importance in the future. Attempts have been made recently in the U.S. to patent plant products that have been traditionally used for centuries in South Asian countries for the same purposes. For example, scientists in the University of Mississippi were granted a US patent in 1995 on the use of turmeric for healing wounds, when it had been used in Ayurvedic medicine for this purpose for centuries in South and Southeast Asia. The patent was withdrawn after its novelty was subsequently challenged by the Indian Council for Scientific and Industrial Research.

The development of techniques for cloning sheep and other mammals from embryonic and differentiated cells in 1996-1997 again provoked worldwide consternation about similar techniques being used to clone human beings. This is not an issue facing Biotechnology in Sri Lanka in the near future since facilities and resources using this technology are presently not available. However, the NARESA Steering Committee on Biotechnology has to be prepared to face this and other similar issues in the long term. The face of Biotechnology is changing rapidly, perhaps more so than in any other academic-industry interface. To keep abreast of these, to advise government through NARESA, accordingly requires that Committee members keep abreast of the latest developments. After many years of effort, membership of the ICGEB was achieved in 1994 for Sri Lanka. ICGEB is a fully fledged UN body. Membership provides access for local scientists to an international database in Biotechnology, expertise of well-known scientists, training opportunities and regular update meetings. Furthermore the ICGEB helps member countries draft legislation on intellectual property, release of genetically modified organisms etc. that are of increasing relevance to this country. NARESA is the focal point for the ICGEB in Sri Lanka and the NARESA Steering Committee on Biotechnology is a critical feature of this link. 


\section{References}

1. Ramasamy R. ( 1993 ). Biotechnology in the year 2000. In: New Biotechnologies - proceedings of a symposium. Agrarian Research and Training Institute, Colombo. pp 1 - 11 .

2. Sasson A. ( 1993 ). In: Biotechnologies in developing countries: present and future. UNESCO, Paris.

3. Marshall E. ( 1997 ). The battle over BRCA1 goes to court: BRCA2 may be next. Seience 278: 1874.

4. Ganashan P. ( 1993 ). Current status and future prospects of biotechnology in Sri Lanka. In: Biotechnology and Crop Improvement in Asia (Ed. J.P. Moss). International Crops Research Institute for Semi-Arid Tropics, Patancheru, India pp. 67-70.

5. Journal of the National Science Council of Sri Lanka, Volume 22, supplement A, (Eds. R. Ramasamy'\& M. Watson). January 1994. NARESA, Colombo.

6. Asian Development Bank (1997) Project report. Ministry of Science, Technology and Human Resources Development, Colombo. 